\title{
The Establishment of the First Metropolitan See of Wallachia
}

\author{
Daniel Gligore
}

\begin{abstract}
The seat of the first Metropolitan See of Wallachiawhich was canonically recognized by the Ecumenical Patriarchate of Constantinople-was established at Curtea de Argeș, alongside with the Princely seat. This ecclesiastical structure-together with the existing princely seats which were attested long before the foundation of Wallachia-demonstrate that "the [Romanian] nation was born spontaneously and naturally as a Christian nation, because conventional Christianity together with the Latin culture contributed to its formation. We are Romanians because we are Christians and we are Christians because we are Romanians."

KEY WORDS: The Metropolitan See of Wallachia, Iachint, Nicolae Alexandru Basarab, Curtea de Argeș, recognition of Metropolitan See.
\end{abstract}

The recognition of the Metropolitan See of Wallachia by the
Ecumenical Patriarchate of Constantinople at the perseverance
of Prince Nicolae Alexandru Basarab-as seen in the two thomoses
of the Ecumenical Synod of May 1359-was an act of great
complexity and political importance for both sides. The documents
mark the establishment of the official relations between the
Metropolitan See of Wallachia and the Ecumenical Patriarchate; the
highest ecclesiastic authority of the Eastern Church (The Orthodox
Church). ${ }^{2}$ These documents also note the adoption of reciprocal
duties, which include the dependence of the Metropolitan See 
of Wallachia on Constantinople, and the inclusion of Muntenia's bishop among the members of the Synod of Constantinople. ${ }^{3}$

The act of recognition of the Metropolitan See is neither an embryonic act nor an act of establishment. It is the acknowledgment of a reality which existed for a long time on the territories from the North of the Danube. ${ }^{4}$ The princes always considered the Orthodox Church-along with all its religious, cultural and social implications - to be a shield for Wallachia; a country assailed by the offensive action of the Catholic kingdoms of Hungary and Poland, which at that time, tended to justify their political expansion outside their own territories through the missionary activities conducted by the Franciscan order; the most active Catholic order of the early $14^{\text {th }}$ century South-Eastern Europe. The fact that "the movement was made with the knowledge and consent of the king"5 - that is the Byzantine Emperor; who was recognized as the protector of the Church since Saint Constantine the Great-is an obvious international act of recognition of Wallachia's independence.

In the mentality of the time, the creation of a new Metropolitan See or the canonical recognition by the Patriarchate of Constantinople was equivalent with a political consecration of a state, in whose territory the respective Metropolitan See was established or recognized. ${ }^{6}$ Furthermore, the legal recognition of the Metropolitan See of Wallachia formalizes the Arges hierarchical continuity as having been in existence for a long time, and strengthens the prestige of Wallachia's princes in relation with the Byzantine Empire, and with the Orthodox countries from Southeast Europe. ${ }^{7}$

The arrival of the prominent hierarch Iachint from Vicina to Arges prior to year 1359 , the recognition of his transfer, and the recognition of the Metropolitan See of Wallachia in the new establishment from Curtea de Argeș on May 1359, consecrates the bond between the Orthodox Church with Wallachia's princes in general, and with the founding Basarab dynasty in particular. The Church that was founded by their predecessors (Argeș I), the Church founded by the first Basarabs (Argeș II), along with the assiduity to recognize the transfer of Metropolitan Iachint from Vicina to Curtea de Arges and the recognition of the Metropolitan See of Wallachia by the Patriarchate of Constantinople, the establishment and the 
material aid sent from Wallachia to Mount Athos, are clear evidence that the Wallachian princes were local and consistently held Eastern Orthodox beliefs. The fact that all the Basarabs were buried in the Orthodox Churches (Nicolae Alexandru Basarab and Basarab, in their church from Câmpulung and their successors in the Metropolitan Cathedral of Curtea de Arges,), is another incontestable piece of evidence attesting that their faith was permanently Orthodox. The Gramata of the Ecumenical Patriarch in 1359 addressed to Nicolae Alexandru, is another piece of evidence attesting the Orthodoxy of the Wallachian prince and his predecessors, the Basarabs, as the patriarch advises him, "to keep unchanged the teachings inherited from their parents."

The seat of the first "lawful metropolitan" of Wallachia was in Curtea de Argeș. Since there is no written document from the fourteenth century to attest the name of the metropolitan city, or the exact location of the first metropolitan see, the existing information as well as the historical deduction infer that the most plausible location was at Saint Nicholas Church, in Curtea de Arges. Furthermore, all metropolitan estates making references to "the Old Document of Neagoe," were near Curtea de Argeș. ${ }^{10}$

As an ecclesiastical center, most historians believe that the metropolitan see was originally at Saint Nicholas Church, but it was later moved to the Monastery of Curtea de Arges.. ${ }^{11}$ Near St. Nicholas Church there is an Orthodox chapel dedicated to San Nicoară, which served as a princely court. In addition to the aulic titulature of "Church of Arges I" attested by the ruins uncovered under the walls of the present church, the resident bishop was attached to prince Seneslau.

At Curtea de Arges Monastery it is certain that there was a metropolitan see during the reign of Vlad the Impaler, whose carved foundation stone was run down from scratch by prince Neagoe Basarab as he built the present Cathedral, which was more beautiful then the one before him.

The existence of a metropolitan bishop is also demonstrated by the architecture of St Nicholas Princely Church in the form of an inscribed Greek cross-a prominent Byzantine style-by its monumental sizes (one of the largest places of worship in that time 
from South-Eastern Europe), as well as by being placed next to the princely court. The architectural elements of this church attest that it was built for the aulic titulature masses, where a metropolitan bishop would serve.

The fact that after the fall of Vidin (1396), the relics of Saint Filofteia were brought to Curtea de Argeș, in St Nicholas Church, is another argument that this was the metropolitan see of a church of aulic titulature in which the metropolitan bishop served frequently.

Other arguments demonstrating the establishment of the metropolitan see at Saint Nicholas Church include some old documents from Neagoe's Church; particularly those referring to a secular trial of Flămânzești estate, and the dispute between Neagoe's establishment and the Metropolia of Târgoviște which placed mutual claims over the estates of the metropolitan church previously built by Vlad the Impaler, upon which Prince Neagoe built his own churches. ${ }^{12}$

Three documents issued by Prince Peter the Youngest to the Monastery of Argeș, in 1560, ${ }^{13}$ certify that Neagoe gave numerous gifts from other cities (Iaşi, Prăvălenii and Horn), as well as the Flămânzești village (for which he gave the townspeople the Sasului Part of the greater domain of Zigonenilor), ${ }^{14}$ to Arges, Monastery during the consecration of his church (August 15, 1517), by the solemn "old document"15 signed by the "patriarch" and "bishops."16

"The Old Document of Neagoe" noted by Mihai Viteazul on 11 May 1597,, ${ }^{17}$ and reproduced on 9 February, $1608,{ }^{18}$ stated that, through the gifts made by Neagoe "which was of the city, from above the Flămânzești valley (bought by late Basarab Voivode from the sons of Cotescu), the Zigonenilor Ocina [part of Zigonenilor Ocinan $\mathrm{n}$. that belonged to the children of Cotescu called, according to other documents, Sasului Part na] ruled to be given by his reign to the town's people instead of the Region from Flămânzești."19

The attitude of Prince Neagoe displeased the people from Argeș due to his handling of a dispute which took place for many centuries. ${ }^{20}$ The dispute was solved by Neagoe Basarab by offering a 
compensatory estate (Sasului Part), attesting that Argeș Monastery is located on the estate of Flămânzești. ${ }^{21}$

The territories around the major cities of Wallachia, originally belonging to the prince, were freely given-shortly after the foundation of the state-either to the nobles or to the monasteries. ${ }^{22}$ Mircea cel Mare donated some villages from around Râmnicu Vâlcea to his the monastery from Cozia. In 1419, Mihail, the son of Mircea, gives the first princely privilege to Câmpulung town. Mircea cel Mare confers privileges to Argeș townspeople, delimitating their properties and the borders of the city. ${ }^{23}$

If Flămânzești estate was given to the townspeople, totally or partially, by Mircea cel Mare, when he established the princely privileges, this means that after the reign of Mircea cel Mare, after 1418, the Metropolitan church (on whose foundations Neagoe Basarab built his church), was located two kilometres outside the Arges city. ${ }^{24}$ According to these historical facts, Vlad the Impaler, the successor of Mircea cel Mare, built the Metropolitan Church in the north of the Flămânzești estate, putting new basis and relocated the Metropolitan seat from the Church of Saint Nicholas in his newly founded church.

The document of Constantin Șerban, issued on July 28, 1654 (immediately after the ascent on the throne), certifies that the estate Flămânzeşti was "in the field of the monastery." ${ }^{25}$ Other documents remind of the Braniştea located "in the field from above the monastery" ${ }^{26}$ or in "the Cerbureni field, from above the Radovan's road." ${ }^{27}$ So, Flămânzești estate coincides with the "monastery field" or with the "hearth of the monastery" the place where Vlad the Impaler's church was built, and for which Neagoe Basarab gave in compensation Sasului Part. ${ }^{28}$

As in that time, the monasteries were built on certain properties, inherited or purchased ${ }^{29}$ in order to avoid quarrels and processes, for Wallachia's Metropolitan Church it was inconceivable that those monasteries to have been built during the Metropolitan See recognition (1359), on a land given by the Prince, and then, after only 80 years, in 1439, this fact no longer to be known, and later on many trials and many quarrels to fallow for the estate of Flămânzești, where the cathedral of Vlad the Impaler was built. 
Certainly in 1359 when the population was less numerous, if Arges, monastery would have existed, Prince Nicolae Alexander Basarab would have been strengthened it with the estate around it, and these endless lawsuits between monks and townspeople would have not taken place. So, the care that Basarab I, Nicolae Alexandru Basarab, Vladislav and the following princes had for the Church, it is an argument for the fact that the monastery could not be mingled with the townspeople. Also, if there monastery existed, any prince later, to the time of Vlad the Impaler, would not have given the estate on which there was the townspeople's monastery.

Even the name "Flămânzești," identical with the name of the hill from the eastern part of the Câmpulung Princely Court, indicate the origin of the settlement. Originally it was the settlement of some afflicted, of some people that came here from other places, because of hunger and other hardships, which have settled around the Princely Court, working to earn a decent living. ${ }^{30}$

There are similar cases in other areas where the population of craftsmen and refugee peasants settled on the prince or lord land, near the fortified princely court, benefiting from the privileges given by the prince or ruler. ${ }^{31}$ Therefore, in the space belonging to the prince, these people coming from other parts settled themselves, later on, when the city was founded, the estate Flămânzești being given to the townspeople and to the Metropolitan Church. The first mention of the townspeople "argișani" is in an ancient document by Dan II, on 30 January $1431 .^{32}$

From all these historical processes and realities we conclude that when the townspeople received the estate of Flămânzeşti (or half of its benefits) there haven't been in this space a metropolitan monastery or church, because the prince had given the full possession to the monastery. According to Pavel Chihaia, the legal situation is explained by taking into consideration the fact that the townspeople have received all or half of the estate of Flămânzești, the other half being given to the Metropolitan See, in order to have a way of access to the estates of that area, that had been received at the foundation: Iașii, Prăvălenii and Cornetu, situated on the northern border of Flămânzești. Vlad the Impaler built up on this estate the Church of The Dormition of The Holy Mother of God. ${ }^{33}$ 
It should also be emphasized the distinction made by Neagoe Basarab himself, between the institution to which the church belonged (the Metropolitan See) and the sanctuary itself. ${ }^{34}$

Neagoe justifiably strengthened his church with these donations of Argeș Metropolitan Church, before moving it to Târgoviște because:

1. His church has stood on the site of the Metropolitan Church

2. It has the same dedication day - The Dormition of The Holy Mother of God-as the Metropolitan Cathedral which was replaced by the monastery. So it was changed only the religious edifice, the dedication day being the same. ${ }^{35}$

In one of the monastery inscriptions, Neagoe Basarab wrote that he found in Curtea de Argess the church with the dedication day of The Dormition of The Holy Mother of God "torn down and stiffened"36 continuing "Great... God the Only Governor... God and unctuous, we pray for this new dedication day being built... don't let it be in desolation...." ${ }^{37}$

So Neagoe Basarab writings refer to the church only as a place of worship which he builds from the ground and which he gives more gifts to. The distinction between the religious institution (monastery, Metropolitan See) and the establishment which accommodates it, is clear in the documents of the time. The Postelnic Marcea donated in 1520 more goods to The Holy Metropolies and Saint Great Church in the town of Târgoviște... Holy and Great Church and Metropolitan See of Târgoviște." ${ }^{38}$ In the commandment of June 23, 1512 it is stated that the gifts donated for the Monastery "Corbii De Piatră" are made to "the Holy Dedication Day and sanctuary of the Holy Mother of God. ... and to the most honourable nuns. ${ }^{39}$ Litigations starting from the confusion made between the proper site which accommodates an institution and the institution itself (monastery, metropolia) were up to the eighteenth century.

In 1782, when Bucovina was taken away from the Austrian Empire, the Bishop of Bucovina claimed that the estates of St. George Church in Suceava, which was the second seat of the Moldovan Metropolia, were entitled to this church and not to the Mitropolity moved to Iasi. 
The disputes continued, the metropolitan protested, arguing that the estates belong to the institution that "they were given to the metropolitan chair" and "wherever they would move, the Metropolies, the wealth, the Metropolitan wealth must remain its, because they were given to it by its founders." ${ }^{40}$

Neagoe Basarab, after the consecration of its church founded in Curtea de Arges, clarifying the properties of the Church from Argeș, ${ }^{41}$ avoids the disputes over these properties between the Argeș Monastery and moved the Metropolitan See of Wallachia to Târgoviște. Instead, the Metropolitan See believes that other estates are being unfairly taken by Argeș Monastery and should be returned or given other estates instead. Even Neagoe gave Băneștii from Ruia $^{42}$ instead of Iași and Prăvălenii near Curtea de Argeș instead of Cornet, a hill next to Flămânzești, and Fleștii from Gura Bațcovului was returned to the Metropolitan See. This restitution of Neagoe Basarab is another argument that these lands belonged to Wallachia Metropolitan See which was in another place of worship. If the seat of the Metropolitan See would have been from the beginning in the space founded by Vlad the Impaler, and later on by Neagoe Basarab, the legal argument put forward by Neagoe Basarab (the continuity of the dedication day) would have been applied to these estates which have belonged both to the Metropolitan See and to the church whose foundations were used for building Neagoe's church, and it would have won. Not being this situation, Neagoe had to give other estates or return to the Metropolitan See what it belonged to the Metropolitan See. ${ }^{43}$

Thus, in the Metropolitan city Curtea de Argeș, two Metropolitan seats have existed, the Metropolia having later on a third seat in Târgoviște.

The first Metropolitan seat had the estates near Curtea de Argeș, these estates being donated, as it is normal, by Nicolae Alexandru Basarab himself, who dealt particularly with his father, Basarab I, both with the building of Saint Nicholas Church in Curtea de Arges and the recognition of Wallachia Metropolitan See and of Iachint. These estates claimed by the people of the new metropolitan church in Târgoviște, when the Metropolitan seat was moved from 
Curtea de Argeș, were won and for them Neagoe either returned others, or he retrocede them, as in the case of Fleștii.

The second Metropolitan seat, with the dedication day of The Dormition of The Holy Mother of God, on whose bases Neagoe Basarb built the Argeș Monastery, had estates around Râmnic and at Măniceşti. These estates were kept by the monastery, without any problem after moving the Metropolitan See to Târgoviște.

The third metropolitan seat was at the Church the Ascension of the Lord, in Târgoviște. This Metropolitan seat being recently moved here, claimed and won only the estates of the first Metropolitan seat from Curtea de Argeș. ${ }^{44}$

The areas where there were given the gifts are another argument for the metropolitan seats. Thus, "Fleștii from Gura Bațcovului with all the land and the two mills," located near Pitești which were taken from Argeș Monastery and given to the Metropolitan See of Târgoviște, were probably donated by Mircea cel Mare to the metropolitan church. The statement is strengthened by another donation of Mircea cel Mare, around the area of Pitești too, ${ }^{45}$ from 20 May 1388, made to his church from Cozia: I have given a mill in the area of Pitești ... and a mill at Râmnic which was given by Prince Dan. ${ }^{46}$ So, Mircea cel Mare donated to the Metropolitan See and to his churches, estates from the area of Pitești.

The estates of the second Metropolitan seat, taken by the Argeș Monastery after moving the Metropolitan See to Târgoviște, were received after Mircea cel Mare. So they were given by Vlad the Impaler to his new metropolitan church on whose foundations Neagoe Basarab would build the beautiful monastery. These estates are bordered by other estates donated by Vlad the Impaler to other monasteries. The estate from Seoaşu, ${ }^{47}$ mentioned in Neagoe "Old Document," and in a document dated from 15 April 1498, was neighbouring the vineyard of Govora Monastery from Copăcel. The latter was given by the Prince Vlad the Impaler. ${ }^{48}$ Moreover, in the vicinity of the Şeoaşu estate from the Argeș Metropolitan See, in the late fifteenth century, it was bought for the Govora Monastery the vineyard "popii Alexe from Argeș." ${ }^{49}$ Other estates of various priests were "near the bishop's land"50 of the Metropolitan See. So, these estates from the area, donated either to the Metropolitan See or to 
other monasteries founded by Vlad the Impaler, belonged to the prince. It is an indication that the founder of the new metropolitan cathedral endowed his church with estates that will remain in the property of the church founded by Neagoe, which kept the place and their patron, under the legal argument put forward by Neagoe Basarab - continuing the dedication day.

Neagoe Basarab, in order to leave instead of the Arges, Metropolitan See a saint sanctuary worthy of remembrance, founded the Argeș Monastery, sparing no effort for his church to be "an occasion of wonder . . . and it is peerless between the monasteries from this country" (Paul Aleppo); "The first in Romania" (Alexander Pelimon); "A real Wallachian Saint Sophia" (W. Derblich) and "to include everything in one word, this church is a jewel" (Paul of Aleppo).

The council held at Curtea de Argeș, after the consecration of the church he founded, at which hierarchs of the Orthodox Churches in the world attended, the gifts made to all the Holy Shrines in the country and throughout the Orthodox world as well as His teachings, ${ }^{51}$ all these prove his Orthodox belief, ${ }^{52}$ the care for ruling the true believer people and his authority at an international level. Neagoe Basarab can be considered the one who introduced the pomposity of the aulic titulature in Wallachia, requirement shown in the listed above, but also in the clothing worn in the votive portrait from Argeș Monastery. The prince has a lilac cape, embroidered with golden thread, crisscrossed by wide, embroidered strips in front, on shoulders and on the bottom. ${ }^{53}$ In the lower right side, it has embroidered the double-headed eagle, the old Asian mark, taken by the Paleologos princes, gradually becoming the tyrants symbol (this title was conferred, from the second half of the twelfth century, to sons, brothers and emperor's sons-in-law, and from the thirteenth and fourteenth centuries to the Serbian sovereigns). The double-headed eagle clock was worn by the Byzantine emperors, Serbian despots and Mircea cel Mare, as shown in his monastery from Cozia. ${ }^{54}$

The ceremonial robe, similar to that of the Byzantines despots (Neagoe was married with Despina Milita, from the Porfirogenet family) with elements of the despots of sebastocrats, is their own 
creation and it is a symbol of their aulic authority for the others around. ${ }^{55}$ Neagoe and his son Theodosius, wear the most precious ceremonial robe, symbolic for the investiture of the king alongside the crown, called granatza. ${ }^{56}$ It was the privilege of the Byzantine emperors, later on being taken by the Serbian princes as well. In Wallachia granatza wasn't used, ${ }^{57}$ which highlights Neagoe's desire of being the follower of the Byzantine and Serbian leaders. The crown, the emblem of the monarchical power, worn by the Romanian rulers, starting with the fourteenth century, was open, similar to that worn by the Western sovereigns, with three jewels in front. Neagoe's Crown, a new type, has five jewels and is lavishly decorated with pearls and precious stones. ${ }^{58}$

For the existence of the Arges Monastery for before Vlad the Impaler, who built it between 1437-1439 and re-consecrated it on August 15, 1439, in order to be a metropolitan cathedral, there are some arguments during his reign or ulterior to the reign of Saint Neagoe Basarab.

An argument is the diptych of the monastery which begins with Basarab the founder, Nicolae Alexandru Basarab. Regarding the diptych, it should be noted that it is from the time of Neagoe Basarab. ${ }^{59}$

Another possible argument is the painting of Nicolae Alexandru Basarab in the monastery. And here it should be mentioned that the present painting is late, after the restoration made during the rule of King Carol I, and it reproduces the painting made by Dobromir of Târgoviște, in 1526, made on the expense of Prince Radu of Afumați, ${ }^{60}$ Neagoe Basarab's son-in-law.

The fact that Negru Vodă Monastery from Câmpulung Mușcel was originally a princely church, having this status until the time of Matei Basarab, who turned it into a convent, ${ }^{61}$ is another argument that the Metropolitan seat was in Curtea de Arges, where there may be a monastery and the monastic people, even mentioned in the synodal document of May 1359: "all the clergy in that country and other holy monks or laymen, to obey and submit to him as a true shepherd for them, and their parent and teacher. ${ }^{62}$ 
NOTES

${ }^{1}$ Mircea Păcurariu, Istoria Bisericii Ortodoxe Române, vol. I, ed. I, (București: Editura Institutului Biblic si de Misiune al Bisericii Ortodoxe Române, 1980), 69.

2 Dinu C. Giurescu, Țara Românească în secolele XIV-XV, (București: Editura Ştiințifică, 1973), 353.

${ }^{3}$ Nicolae Dobrescu, Întemeierea mitropoliilor și a celor dintâi mănăstiri din țară, (București: Tipografia Cărților Bisericești, 1906), 39-49.

${ }^{4}$ Constantin C. Giurescu, „Întemeierea Mitropoliei Ungrovlahiei," Biserica Ortodoxă Română, 7-10, (1959), 678.

${ }^{5}$ Fontes Historiae Daco-Romanae / Izvoarele istoriei românilor, vol. IV, Scriitori și acte bizantine sec. IV-XV, (Fontes, IV) publ. by Haralambie Mihăescu, Radu Lăzărescu, Nicolae-Şerban Tanaşoca, Tudor Teoteoi, Bucureşti: Editura Academiei, 1982), 201-03.

${ }^{6}$ C. Marinescu, ,Înfiiințarea Mitropoliilor în Țara Românească și în Moldova,” Analele Academiei Române, Memoriile Secțiunii Istorice (A.R.M.S.I.), seria a III-a, tomul II, mom. 6, (Bucureşti: Editura Academiei, 1924), 248.

${ }^{7}$ Radu Ştefan Vergatti, „Mitropolia Țării Românești sau a Ungrovlahiei.” In Domnitorii şi ierarhii Țării Româneşti, Ctitoriile şi mormintele lor, (Bucureşti: Editura Cuvântul Vieții a Mitropoliei Munteniei şi Dobrogei, 2009), 481.

${ }^{8}$ Documente privind Istoria românilor (D.I.R.), B Țara Românească, vol. I, veac XIII-XV, (1247-1500), (București: Editura Academiei, 1953), 14-6.

${ }^{9}$ Documente privind Istoria românilor (D.I.R.), B Țara Românească, vol. I, veac XIII-XV, (1247-1500), (București: Editura Academiei, 1953),13-4.

${ }^{10}$ Pavel Chihaia, Din cetățile de scaun ale Țării Românești, (București: Editura Meridiane, 1974), 46-66.

${ }^{11}$ Radu Ştefan Vergatti, „Mitropolia Țării Românești sau a Ungrovlahiei,” in loc. cit., 478.

${ }^{12}$ Pavel Chihaia, „Cele două locaşuri ale Mitropoliei din Curtea de Argeș, deduse din hrisoavele bisericii lui Neagoe Basarab," Mitropolia Olteniei, 7-8, XIX (1967), 599.

${ }^{13}$ Documente privind Istoria românilor (D.I.R.), B sec. XVI, vol. III, no. 146, 121; no. 158, 132, no. 159, 133.

${ }^{14}$ Pavel Chihaia, Din cetățile de scaun ale Țării Românești, ed. cit., 48.

15 "Svitoc" is an official paper roll shaped.

${ }^{16}$ It is about the Patriarch of Constantinople Teolipt and about the five metropolitans who committed the consecration of the church founded by Neagoe, said Gavriil Protea in the Life of St Niphon.

${ }^{17}$ The Old Document of Mihai Viteazul states that a number of gifts strengthened by this voivode "were given by the late Neagoe BAsarab Holy Monasteries .... and is written in the Old Document of Neagoe Basarab. Şi am văzut şi domnia mea svitocul pe care la făcut domnia lui de miluire." DIR, $B$., XVI, VI, nr. And I also saw my reign, the Old Document made by his reign of mercy." Documente privind Istoria românilor (D.I.R.),B., XVI, VI, no. 282, 265. 
${ }^{18}$ The document records that Radu Şerban "the nephew of the late voivode Basarab . . . seeing the venerable "Old Document " of the lord's grandfather, Prince Basarab I, old and dark... I renewed and I strengthened with the charter of my reigh." Documente privind Istoria românilor (D.I.R.),B., XVII, I no. 273, p. 293-296. 273, 293-96. Radu Şerban a înlocuit „svitocul” lui Neagoe cu alt hrisov cu acelaşi conținut care se păstrează. Radu Serban replaced Neagoe basarab`s "Old Document " with another "Old Document " with the same content which is preserved. Realitatea este confirmată şi de faptul că pasaje întregi din hrisovul lui Radu Şerban sunt identice cu una din pisaniile lui Neagoe Basarab de pe ctitoria sa argeşeană. The reality is confirmed also by the fact that the many passages of the "Old Document " of Radu Serban are identical to one of Neagoe Basarab`s inscriptions from its foundation from Arges area. Pavel Chihaia, „Cele două locaşuri ale Mitropoliei din Curtea de Argeş, deduse din hrisoavele bisericii lui Neagoe Basarab," în loc. Pavel Chihaia, " The two seats of Curtea de Arges Mitropoly, inferred from the church "Old Documents " of Neagoe Basarab," in loc. cit., 600 .

${ }^{19}$ Documente privind Istoria românilor (D.I.R.), B., XVII, I, no. 273, 293-96.

${ }^{20}$ Ibidem.

21 Ion Ionaşcu, „Din relațiile mănăstirii Curtea de Argeş cu orăşenii argeșeni," Revista istorică română, XIV (1944), fasc. 4, 458.

${ }^{22}$ Ion Donat, „Le domaine princier rural en Valachie (XIV $-X V I^{e}$ siècles,” Revue Roumaine d'Histoire, tome VI, 1967 (2), 227-29.

${ }^{23}$ Pavel Chihaia, „Cele două locașuri ale Mitropoliei din Curtea de Argeș, deduse din hrisoavele bisericii lui Neagoe Basarab," in loc. cit., 604-05; Pavel Chihaia, Din cetățile de scaun ale Țării Românești, ed. cit., 57.

${ }^{24}$ Ibid.

${ }^{25}$ The Document of Constantin Şerban is in Serviciul Municipiului Bucureşti al Arhivelor Naționale (S.M.B.A.N.), Fond. Episcopia Argeş, Orig. LXIX bis/14.

${ }^{26}$ D.I.R., XVI, B, II, nr. 132, p. 130; no. 49, 46.

27 According to the documents from 17 july 1721 kept in Serviciul Municipiului Bucureşti al Arhivelor Naționale (S.M.B.A.N.), Fond Episcopia Argeş, Mss. 168, f. 56 and from 26 January 1811 păstrat în Serviciul Municipiului Bucureşti al Arhivelor Naționale (S.M.B.A.N.), Fond Episcopia Argeș, Mss. 168, f. 59.

${ }^{28}$ Pavel Chihaia, Din cetățile de scaun ale Țării Româneşti, ed. cit., 54.

${ }^{29}$ Ion Donat, Le domaine princier rural en Valachie (XIVe-XVI ${ }^{e}$ siècles), ed. cit., 215.

${ }^{30}$ Pavel Chihaia, Din cetățile de scaun ale Țării Românești, ed. cit., 55-6.

${ }^{31}$ P. P. Panaitescu, „Oraşe din Moldova,” Magazin Istoric, 9, III (1969), 15.

${ }^{32}$ Documenta Romaniae Historica, seria B, Țara Românească (D.R.H.) ser. B, Țara Românească, vol. I, (1247-1500), I, no. 69, 130-31.

${ }^{33}$ Pavel Chihaia, Din cetățile de scaun ale Țării Românești, ed. cit.,55.

${ }^{34}$ Ibidem.

${ }^{35}$ Ibidem, 57. 
36 "Neîntărită" meaning without complete documentation.

${ }^{37}$ Gheorghe Mihăilă, Dan Zamfirescu, Literatura română veche (14021647), vol. I, (București: Editura Tineretului, 1969), 160.

${ }^{38}$ Documente privind Istoria românilor (D.I.R.), B. Țara Românească, XVI, B, I, no. 159, 161.

${ }^{39}$ Ibidem, no. 78, p. 77.

${ }^{40}$ Constantin Erbiceanu, Istoria Mitropoliei Moldovei, Sucevei şi a Catedralei Mitropolitane din Iaşi, (Bucureşti, Tipografia Cărților Bisericești, 1888), 300.

${ }^{41}$ These proprieties are: Seoaşul near Ocnele Mari, Bârseştii, Ruda near Olt an Măniceștii, on their way to Curtea de Argeș and Pitești. Pavel Chihaia, Din cetățile de scaun ale Țării Românești, ed. cit.,58.

${ }^{42}$ Documente privind Istoria românilor (D.I.R.), XVI, B, II, no. 125, 123-24; Documente privind Istoria românilor (D.I.R.), XVI, B, III, no. 199, 165-66.

${ }^{43}$ Pavel Chihaia, Din cetățile de scaun ale Țării Românești, ed. cit., 58.

${ }^{44}$ Ibidem, 59.

${ }^{45}$ Dinu C. Giurescu, Țara Românească în secolele XIV-XV, ed. cit.,98.

${ }^{46}$ Documenta Romaniae Historica (D.R.H.),Tara Românească, B, I, no. 9, 23-8.

${ }^{47}$ Situated near Ocnele Mari.

${ }^{48}$ Documenta Romaniae Historica (D.R.H.),Țara Românească, B, I, no. 263, 460-61; D.I.R., XVI, B, I, no. 9, 15-7.

${ }^{49}$ Documenta Romaniae Historica (D.R.H.),Tara Românească, B, I, no. 220, 351-55; D.I.R., XVI, B, I, no. 9, p. 16, no. 129,128.

${ }^{50}$ Documenta Romaniae Historica (D.R.H.),Ţara Românească, B. no. 15, 43-8; D.R.H., B, I, no. 303, 495-96.

${ }^{51}$ Ioan-Gheorghe Rotaru, "Aspecte privitoare la Învățăturile lui Neagoe Basarab către fiul sau Theodosie," Păstorul ortodox, (Curtea de Argeș: Editura Arhiepiscopiei Argeşului şi Muscelului, 2012), 12-41.

${ }^{52}$ The care of St. Neagoe Basarab for knowing and confessing the Orthodox faith was a permanent priority. The prince was a fine theologian able to have correspondence on theological themes with the great scholars of the time. To be clear on the differences between Catholicism and Orthodox faith, Neagoe consulted Manuel of Corinth (approx. 1460-1551) - the famous theologian of that time, professor at the Patriarchate School and high ritor at the Ecumenical Patriarchate-who sent him letter listing the main errors of the Latins: the procession of the Holy Spirit from the Son as well (Filioque), the confusion of the Being with the divine energy, use of azyme at Communion, formulas and gestures wrongly made during the service of Baptism and other Sacraments, the laxist way in which priesthood is conceived and practiced, the belief in the Purgatory, different perpetration of the Cross sign, etc. The letter to Neagoe Basarab is preserved today between the Greek manuscripts of the University of Illinois Library. A photocopy of the manuscript was brought in the country by Professor dr. Dan Zamfirescu and has been translated by Nicolae Serban Tanaşoca in the magazine Tabor. Nicolae Serban Tanaşoca, "The letter of the great ritor of the 
Ecumenical Patriarchate, Manuel from Corinth to Neagoe Basarab" in Tabor, Romanian culture and spirituality magazine published by the Metropolitan of Cluj, Alba, Crisana and Maramures, Year V, nr. 8 November 2011, 5-11.

${ }^{53}$ P. P. Panaitescu, „L`aigle byzantine sur les vétements des princes roumains du Moyen Age," Academie Roumaine. Bulletin de la séction historique, XII (1930), 64-7.

${ }^{54}$ Răzvan Theodorescu, „Despre un însemn sculptat şi pictat de la Cozia (în jurul „despotiei” lui Mircea cel Bătrân”), Studii şi Cercetări de Istoria Artei, seria Artă Plastică, tom 16, 2 (1969), 194.

${ }^{55}$ Radu Ştefan Vergatti, Neagoe Basarab. Viața, opera, domnia, Ediția a II-a revăzută şi adăugită, (Curtea de Argeș: Editura Episcopiei Argeşului şi Muscelului, 2009), 80-1.

${ }^{56}$ Corina Nicolescu, Istoria costumului de curte în țările române, secolele XIV-XVIII, (București: Editura Ştiințifică, 1970),123.

${ }^{57}$ Ibid.,127.

${ }^{58}$ Corina Nicolescu, „Les insignes du pouvoir-Contribution à l'histoire du cérémonial de cour roumain," Revue des Études Sud-Est Européennes, XV (1977) $2,241-42$.

59 Aurelian Sacerdoțeanu, „Pomelnicul Mănăstirii Argeşului,” Biserica Ortodoxă Română, LXXXIII (1965) 3-4, 297-330; Serviciul Municipiului București al Arhivelor Naționale (S.M.B.A.N.), Fond Episcopia Argeș, Condica, no. 742, f. 1.

${ }^{60}$ Buried in the Cathedral of Curtea de Arges. Nicolae Iorga, Inscriptii din Bisericile României, vol. I, (București: Institutul de Arte Grafice Minerva, 1905), 148-49.

${ }^{61}$ The prince, in the Old Document given to the monastery on 10 April 1647 says "I did't left for haggling what it was first, namely to be a parish church, which it was made into a monastic house." Serviciul Municipiului București al Arhivelor Naționale (S.M.B.A.N.), Fond Mănăstirea Câmpulung, Mss. 204, f. 76-80; Pr. I. Răuțescu, Câmpulung Muscel. Monografie istorică, (Câmpulung: Tipografia Gh. Gh. Vlădescu, 1943), 78.

${ }^{62}$ Documente privind Istoria românilor (D.I.R.), B, I, 13-4. 